\title{
Determination of optimum hull form for passenger car ferry with regard to its sea-keeping qualities and additional resistance in waves
}

Tomasz Cepowski, Ph. D.

Szczecin Maritime University

ABSTRACT

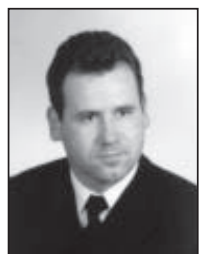

This paper presents a method which makes it possible to determine optimum hull form of passenger car ferry with regard to selected sea-keeping qualities and additional resistance in waves. In the first phase of investigations a hull form characterized by the highest qualities was selected from the list of similar ships. Next, its optimum dimension ratios were determined. Design criteria were formulated by using a method based on deterministic scenarios, but objective functions of partial targets were determined in the form of artificial neural networks. To select the best design variants elements of fuzzy logic were used, that made it possible a.o. to show merits of the design by means of linguistic variables. Such approach made it possible to find the best hull form and its dimensions from the point of view of all considered criteria simultaneously.

Keywords: sea-keeping qualities, roll-on-roll-off ferry ship, rolling, transverse accelerations, vertical accelerations, motion sickness index, additional resistance in waves, ship hull form, ship design parameters, artificial neural networks, fuzzy logic.

\section{INTRODUCTION}

In the ship design process design solutions complying both with economic criteria and technical constraints, are searched for. The economic criteria contain a set of ship owner's requirements to which can belong a.o. ship service speed of a significant impact on ship operation profitability on a given shipping route. As the ship is often operated in heavy weather conditions the reaching of its assumed service speed depends a.o. on its additional resistance in waves. And, for certain types of ships, e.g. passenger car ferries, their non-susceptibility to weather conditions, i.e. the so called good sea-keeping qualities, constitutes a more - and- more important technical limitation. The additional ship resistance in waves and good sea-keeping qualities are strongly dependent on ship's hull form and dimensions. Therefore modeling the ship qualities should be performed already in the preliminary ship design stage. Selection of a non-suitable hull form and dimensions of a ship irreversibly worsens its design merits and any change of dimensions of a built ship is economically unprofitable. In $[1,3]$ a method which makes it possible to take into account the ship sea-keeping qualities and additional ship resistance in waves in the phase of parametric design, is presented. As a result of the research, optimum values of ship dimensions and certain global coefficients characterizing hull form of a ro-ro ferry ship were determined. However the aim of the research presented in this paper was to model a geometrically described hull form and to determine an optimum hull form with regard to its sea-keeping qualities and additional resistance in waves. The obtained results are presented with the use of an example design task.

\section{DESIGN TASK}

In the research the following design tasks were formulated: to find such hull form of the ro-ro ferry, which minimizes values of the design criteria at fulfilled assumed constraints for the passenger car ferry sailing in heavy weather conditions.

In the design task the following were assumed:

* ship design parameters describing its hull form, considered independent variables:

- L/B

- B/d

- CB

- CWL

where: L, B, d-ship length, breadth and draught, respectively, CB - block coefficient of underwater part of hull, CWL - waterplane coefficient;

constraints:

- theoretical displacement $\mathrm{V}=13723 \mathrm{~m}^{3}$

- range of $\mathrm{L} / \mathrm{B}$ : from 5.17 to 6.74

- range of $\mathrm{B} / \mathrm{d}$ : from 3.22 to 4.46

- range of $\mathrm{CB}$ : from 0.6 to 0.64

- range of CWL : from 0.8 to 0.85

- the initial transverse metacentric height $\mathrm{GM}=1 \mathrm{~m}$ 


\section{METHOD}

To solve the problem was elaborated a method consisted of the two phases:

1. On the basis of the list of similar ships - determination of alternative design variants and selection of the best one (Fig. 1)

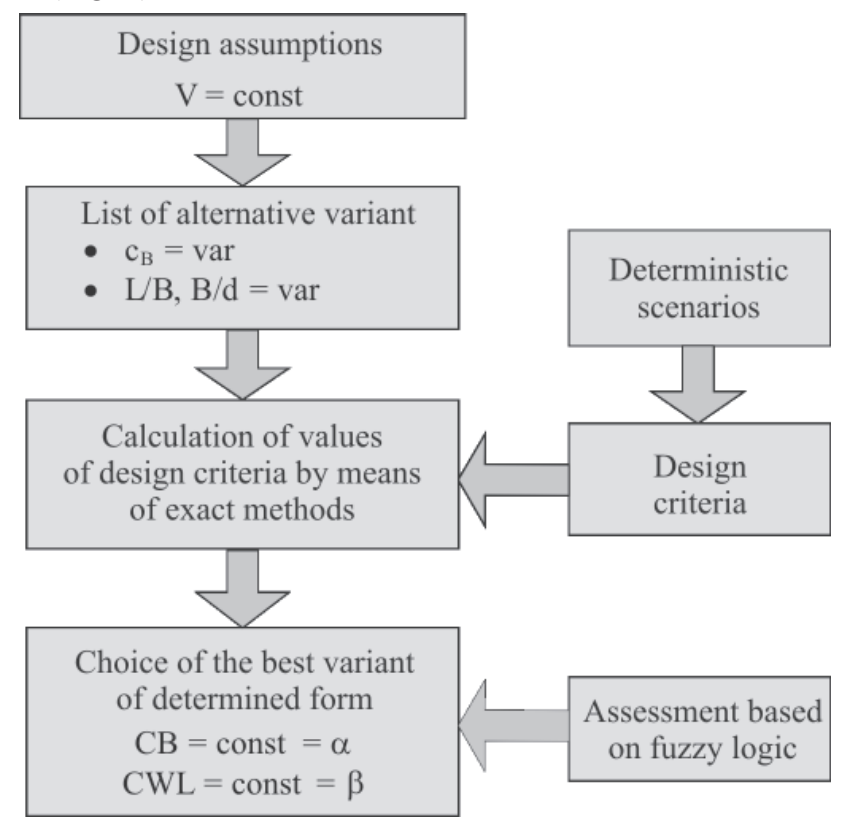

Fig. 1. Algorithm showing the $1^{\text {st }}$ phase of the research

2. On the basis of the best hull form variant selected in the $1^{\text {st }}$ phase - selection of the optimum ratios of ferry ship dimensions (Fig. 2).

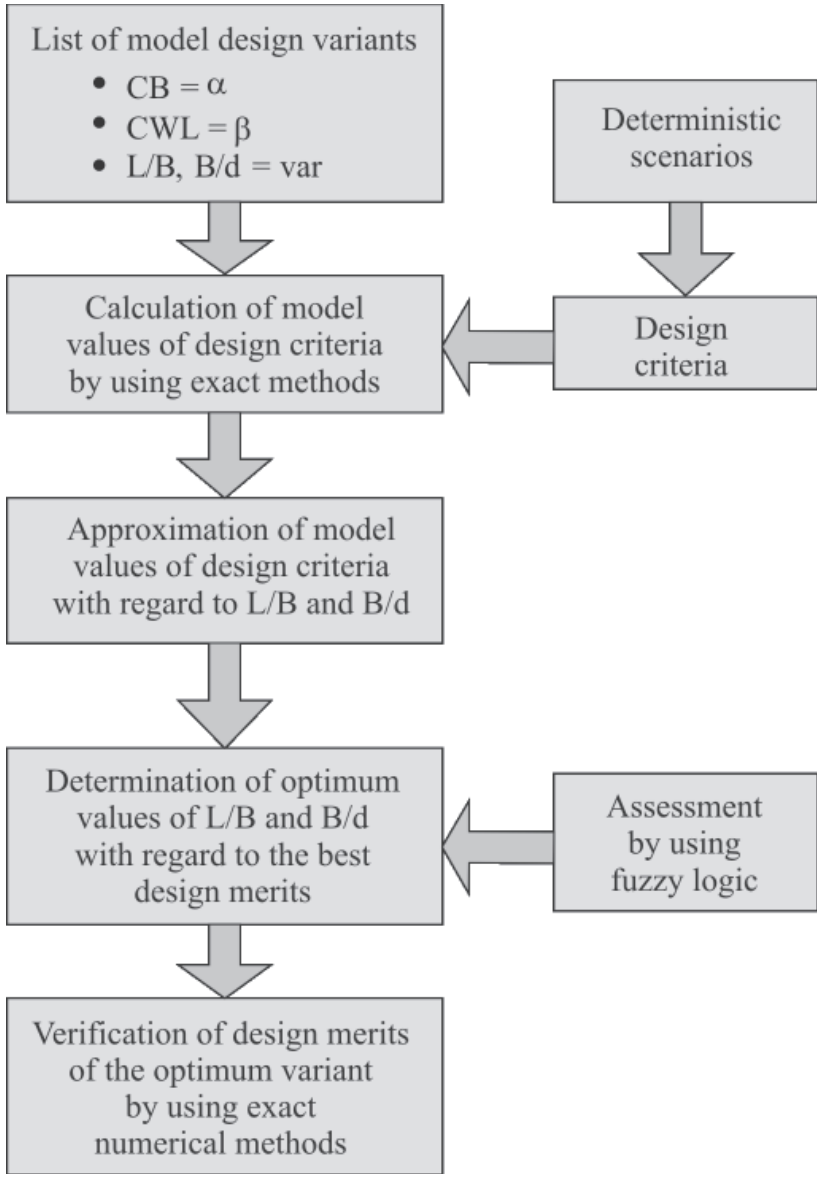

Fig. 2. Algorithm showing the $2^{\text {nd }}$ phase of the research
The assessment process of design variants carried out in both research phases was based on the below given design criteria.

\section{DESIGN CRITERIA}

One of the crucial design problems of ro-ro ferries is to ensure appropriate damage stability. The ship stability criteria being in force are rather far from taking into account the complex physical phenomena associated with ship hydromechanics, and they are based first of all on physical parameters calculated for a ship in still water conditions. Hence the application of design criteria inadequate to the conditions in which the ship operates does not ensure a sufficient level of safety. The IMO has initiated efforts aimed at undertaking a research on elaboration of new standards for ship stability assessment. One of the ways to solve the problem is elaboration of methods for investigating the intensity of ship rolling motion (e.g. [12]) or probability of ship capsizing (e.g. [10]). In the case of ro-ro ferry ships such investigations are aimed at elaboration and improvement of simulation models of sinking process of damaged ferry in given conditions (acc. [8]). The example models are presented in $[13,15]$. The above referred research makes it possible to simulate ferry sinking process however any design criteria have not yet evolved from that.

The design criteria assumed in this research are to an extent associated with the above mentioned reccomendations, as thy are based on statistical values of ship response in waves. For their formulation a method based on deterministic scenarios [16], was used, hence the following scenarios were assumed:

Scenario no. 1: the design ferry sails with the speed $v=15$ $\mathrm{kn}$ in the statistical heavy weather conditions (the significant wave height of $3 \mathrm{~m}$, the characteristic wave period in the range from $3 \mathrm{~s}$ to $18 \mathrm{~s}$.), the ship encounters the wave from the most unfavourable directions.

Scenario no. 2: the designed ferry is in the following damage state : its side plating amidships has been broken at the level of car deck, the disable ship is in the statistical heavy weather conditions (the significant wave height of $3 \mathrm{~m}$, the characteristic wave period in the range from $3 \mathrm{~s}$ to $18 \mathrm{~s}$.), the ship heads the wave at the encounter angle $\beta=120^{\circ}$ (where: $180^{\circ}$ - head wave, $0^{\circ}$ - following wave).

Such approach made it possible to formulate the following design criteria:

For Scenario no. 1:

1. As- small- as- possible value of the motion sickness index MSI (acc. ISO 2631/3), [9] for the wave encouter angle $\beta$ $=120^{\circ}$

2. As- small- as- possible value of the additional ship resistance in waves $\mathrm{R}$, for $\beta=180^{\circ}$

3. As -small-as-possible significant value of the roll angle $\varphi$ , for $\beta=30^{\circ}$

4. As-small-as-possible value of the transverse accelerations at the car deck, $a_{t}$, acc. [16], in the point P2 in Fig. 3 , for $\beta=30^{\circ}$

5. As-small-as-possible value of the vertical accelerations at the car deck, $\mathrm{a}_{\mathrm{v}}$, acc. [16], in the point P2 in Fig. 3.

For Scenario no. 2:

6. As-low-as-possible number of events of flooding the car deck in the place of broken side plating, $\mathrm{L}_{\mathrm{GW}}$, for the wave ancounter angle $\beta=120^{\circ}$, in the point P1 in Fig. 3 .

Fulfilment of the criteria no. 1, 3, 5 ensures an appropriate voyage comfort for passengers, moreover the criterion no. 3 
ensures safety of ship stability, resulting from a lower intesity of ship rolling motions. Fulfilment of the criterion no. 4 leads to a lower hazard due to possible shift of vehicles on the car deck. Fulfilment of the criterion no. 6 can lower a number of flooding events of the car deck due to broken side plating, and thus decrease mass of the water flooded on the deck, that can make sinking time of the ship longer. And, fulfilment of the criterion no. 2 can lower a decrease of ship speed in waves, and thus operational costs due to lower fuel consumption.

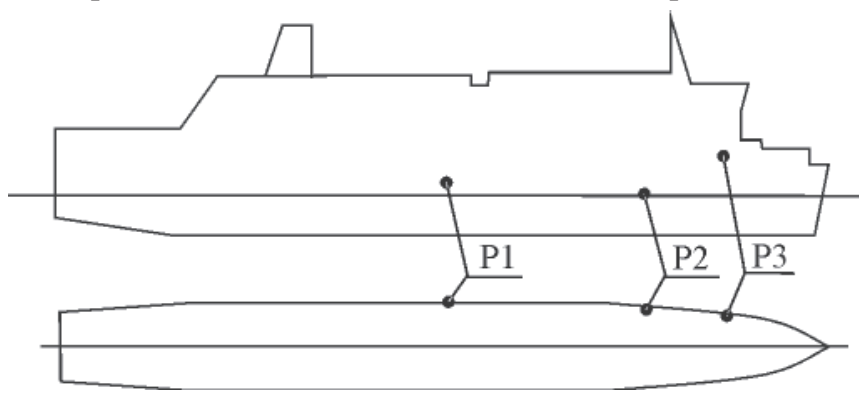

Fig. 3. The coordinates of the points P1, P2, P3 for which the following quantities were calculated: number of car deck flooding events - in the point $P 1(0.5 \mathrm{~L}, 0.49 \mathrm{~B}, d+1 \mathrm{~m})$, transverse accelerations - in the point $P 2$ $(0.75 \mathrm{~L}, 0.45 \mathrm{~B}, d)$, vertical accelerations - in the point $P 3(0.8 L, 0.32 B, 2 d)$, where: $L$-ship length, $B$-ship breadth, $d$-ship draught

\section{THE $1^{\text {st }}$ PHASE OF THE RESEARCH}

The $1^{\text {st }}$ phase of the research was aimed at the finding - on the basis of the list of alternative variants - a hull form of the best merits. In the investigations were used eight ro-ro ferries whose dimensions and hull forms are presented in Tab. 1 and Fig. 4.
Tab. 1. List of alternative design variants, $V=13723 \mathrm{~m}^{3}, C B, L / B, B / d=v a r$

\begin{tabular}{|c|c|c|c|c|}
\hline Design variants & CB & CWL & L/B & B/d \\
\hline Variant no. 1 & 0.599 & 0.809 & 5.68 & 3.22 \\
\hline Variant no. 2 & 0.644 & 0.828 & 6.17 & 3.58 \\
\hline Variant no. 3 & 0.637 & 0.811 & 5.71 & 3.40 \\
\hline Variant no. 4 & 0.616 & 0.828 & 5.17 & 4.46 \\
\hline Variant no. 5 & 0.620 & 0.831 & 6.74 & 3.90 \\
\hline Variant no. 6 & 0.634 & 0.852 & 5.57 & 3.77 \\
\hline Variant no. 7 & 0.626 & 0.850 & 5.64 & 3.5 \\
\hline Variant no. 8 & 0.610 & 0.804 & 6.74 & 4.04 \\
\hline
\end{tabular}

For each of the design variants given in Tab. 1 statistical values of the assumed design criteria were calculated. The conventional ITTC wave spectrum was assumed. The calculations were carried out by means of the exact numerical methods included in the SEAWAY software based on the theory of two-dimensional flow. For calculation of hydrodynamic coefficients the Frank's method was applied [5]. The accuracy tests of the SEAWAY software, presented in [9], have shown that its calculation accuracy is high. For calculations of the additional ship resistance in waves the Gerritsma-Beukelman method was used [6].

To the investigations were applied such values of the design criteria which reached their maxima in the assumed statistical wave conditions (i.e. the significant wave height equal to $3 \mathrm{~m}$, the characteristic wave period within the range from $3 \mathrm{~s}$ to $18 \mathrm{~s}$.). It enabled to eleminate influence of the wave parameters on ship responses and to lower the number of independent variables in the design task in question. The results of calculations are presented in Tab. 2.
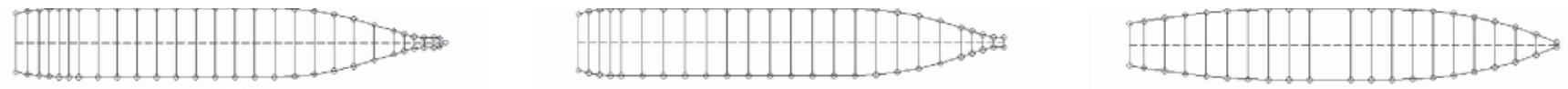

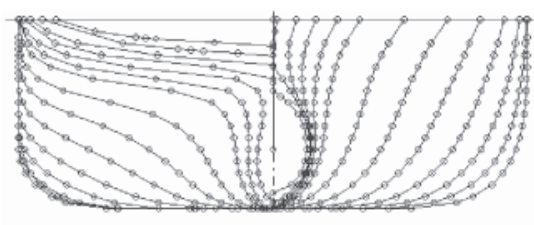

Variant no. 1
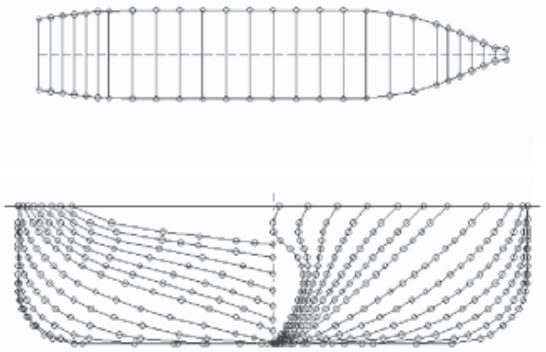

Variant no. 4

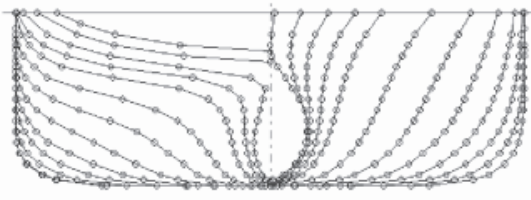

Variant no. 2
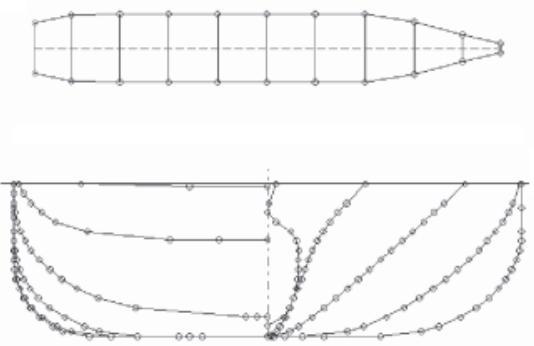

Variant no. 5

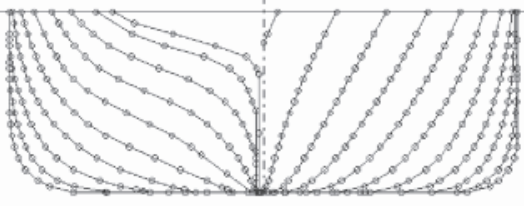

Variant no. 3
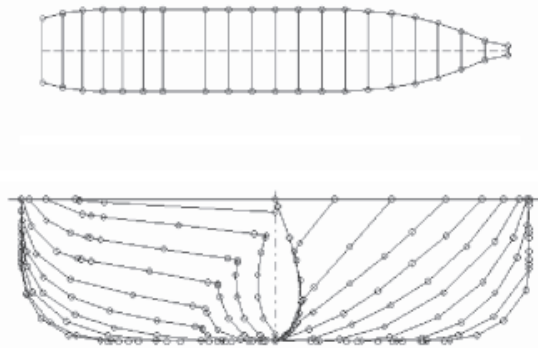

Variant no. 6
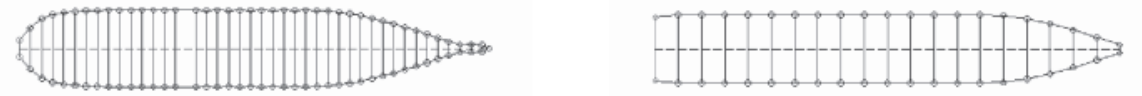

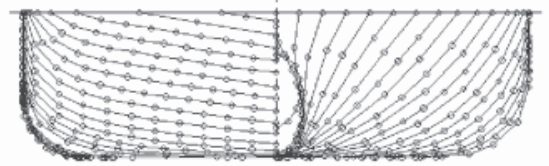

Variant no. 7

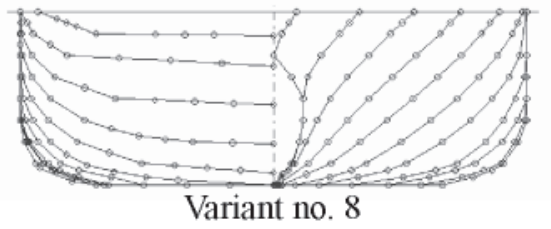

Variant no. 8

Fig. 4. Hull forms of alternative design variants of ro-ro ferry, $V=13723 \mathrm{~m}^{3}, C B, L / B, B / d=v a r$ 
Tab. 2. Values of the design criteria used in the $1^{\text {st }}$ phase of the research, where: MSI - motion sickness index, a-transverse acceleration at the car deck, $a_{v}$-vertical accelerations, $\varphi$ - significant amplitude of ship rolling, $R$-additional ship resistance in waves, $L_{G W}$ - hourly number of car deck flooding events in the place of broken side plating

\begin{tabular}{|c|c|c|c|c|c|c|}
\hline $\begin{array}{c}\text { Design } \\
\text { variants }\end{array}$ & $\begin{array}{c}\mathbf{M S I} \\
{[\%]}\end{array}$ & $\boldsymbol{\varphi}\left[{ }^{\circ}\right]$ & $\begin{array}{c}\mathbf{a}_{\mathbf{v}} \\
{\left[\mathbf{m} / \mathbf{s}^{2}\right]}\end{array}$ & $\begin{array}{c}\mathbf{a}_{\mathbf{t}} \\
{\left[\mathbf{m} / \mathbf{s}^{2}\right]}\end{array}$ & $\begin{array}{c}\mathbf{R} \\
{[\mathbf{k N}]}\end{array}$ & $\begin{array}{c}\mathbf{L}_{\mathbf{G W}} \\
{[\mathbf{1} / \mathbf{h}]}\end{array}$ \\
\hline Variant no. 1 & 49.1 & 7.79 & 2.14 & 1.33 & 195.8 & 267.5 \\
\hline Variant no. 2 & 37.8 & 6.50 & 2.02 & 1.11 & 165.1 & 285.4 \\
\hline Variant no. 3 & 35.9 & 2.16 & 2.00 & 0.60 & 163.6 & 271.9 \\
\hline Variant no. 4 & 16.6 & 4.32 & 1.77 & 0.73 & 187.9 & 285.1 \\
\hline Variant no. 5 & 24.4 & 7.70 & 1.87 & 1.31 & 178.2 & 283.4 \\
\hline Variant no. 6 & 20.9 & 9.13 & 1.83 & 1.56 & 176.6 & 285.5 \\
\hline Variant no. 7 & 30.4 & 8.00 & 1.94 & 1.36 & 174.0 & 289.9 \\
\hline Variant no. 8 & 17.7 & 6.08 & 1.78 & 1.04 & 148.3 & 278.9 \\
\hline
\end{tabular}

In the further part of the research the best design variant was selected with the use of a method based on fuzzy logic elements.

\section{APPLICATION OF FUZZY LOGIC ELEMENTS TO SELECTION OF THE BEST DESIGN SOLUTION}

Fuzzy logic finds its application wherever the use of classic logic creates a problem consisted in difficulty of mathematical description of a process or when to calculate or select variables for solving a problem is not possible. In the design problem in question fuzzy logic was used as an element which aids to assess quality of a design variant (of low, mean or high merits) and to decide on choice of the best design (of the best merits).

In the $1^{\text {st }}$ research phase the set of solutions given in Tab. 2 was fuzzyfied with the use of the attribution function decribed by the Eq. (1):

$$
\mu\left(x_{i}\right)=\left\{\begin{array}{ccc}
1 & \text { for } & x_{i} \geq \alpha_{2(i)} \\
0 & \text { for } & x_{i} \leq \alpha_{1(i)} \\
\frac{x_{i}-\alpha_{1(i)}}{\alpha_{2(i)}-\alpha_{1(i)}} & \text { for } & \alpha_{1(i)}<x_{i}<\alpha_{2(i)}
\end{array}\right.
$$

where:

$\mu\left(x_{i}\right) \quad-$ value of attribution function for $\mathrm{i}$-th design criterion $\left(\mathrm{i}=\right.$ MSI, $\varphi, \mathrm{a}_{\mathrm{v}}, \mathrm{a}_{\mathrm{t}} \mathrm{R}, \mathrm{L}_{\mathrm{GW}}$ )

$\mathrm{x}_{\mathrm{i}} \quad-$ value of $\mathrm{i}$-th design criterion (from Tab. 2)

$\alpha_{1(\mathrm{i})}, \alpha_{2(\mathrm{i})}-$ threshold values acc. Tab. 3 .

The graphical form of the function (1) as well as its liguistic interpretation is presented in Fig. 5; and, values of the coefficients $\alpha_{1(\mathrm{i})}, \alpha_{2(\mathrm{i})}$ are given in Tab. 3.

Tab. 3. Values of the coefficients $\alpha_{1(i)}$ and $\alpha_{2(i)}$ for the design criteria: MSI-motion sickness index, $a_{t}$-transverse acceleration at the car deck,

$a_{v}$-vertical accelerations, $\varphi$ - significant amplitude of ship rolling,

$R$-additional ship resistance in waves, $L_{G W}$ - hourly number of car deck flooding events in the sector of broken side plating

\begin{tabular}{|l|c|c|c|c|c|c|}
\hline & $\begin{array}{c}\text { MSI } \\
{[\%]}\end{array}$ & $\begin{array}{c}\boldsymbol{\varphi} \\
{\left[{ }^{\mathbf{0}}\right]}\end{array}$ & $\begin{array}{c}\mathbf{a}_{\mathbf{v}} \\
{\left[\mathbf{m} / \mathbf{s}^{2}\right]}\end{array}$ & $\begin{array}{c}\mathbf{a}_{\mathbf{t}} \\
{\left[\mathbf{m} / \mathbf{s}^{2}\right]}\end{array}$ & $\begin{array}{c}\mathbf{R} \\
{[\mathbf{k N}]}\end{array}$ & $\begin{array}{c}\mathbf{L}_{\mathbf{G W}} \\
{[\mathbf{1} / \mathbf{h}]}\end{array}$ \\
\hline$\alpha_{1(\mathrm{i})}$ & 27.43 & 4.48 & 1.89 & 0.92 & 164.13 & 274.97 \\
\hline$\alpha_{2(\mathrm{i})}$ & 38.27 & 6.81 & 2.02 & 1.24 & 179.97 & 282.43 \\
\hline
\end{tabular}

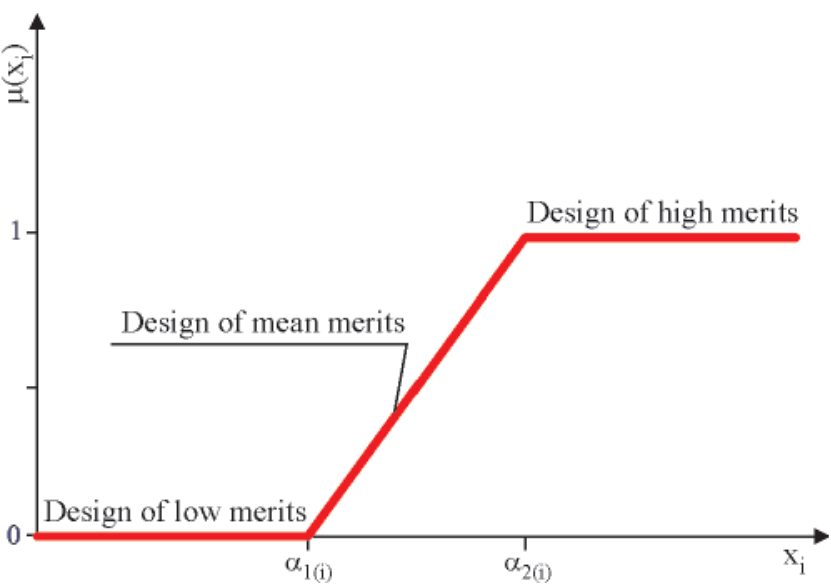

Fig. 5. Attribution function acc. Eq. (1)

Next, assessment of the design solutions fuzzyfied with the use of Eq. (1) was performed. To assess design quality the minimizing operator MIN was applied in accordance with Eq. (2):

$\mathrm{MIN}=\operatorname{MIN}\left(\mu(\mathrm{MSI}), \mu(\mathrm{R}), \mu(\varphi), \mu\left(\mathrm{a}_{\mathrm{t}}\right), \mu\left(\mathrm{a}_{\mathrm{v}}\right), \mu\left(\mathrm{L}_{\mathrm{GW}}\right)\right)$

where:

MIN - minimizing operator

$\mu(\mathrm{MSI}), \mu(\mathrm{R}), \mu(\varphi), \mu\left(\mathrm{a}_{\mathrm{t}}\right), \mu\left(\mathrm{a}_{\mathrm{v}}\right), \mu\left(\mathrm{L}_{\mathrm{GW}}\right)-$ attribution function of the design criteria: MSI - motion sickness index, $\mathrm{a}_{\mathrm{t}}$ - transverse acceleration at the car deck, $\mathrm{a}_{\mathrm{v}}-$ vertical accelerations, $\varphi-$ significant amplitude of ship rolling, $\mathrm{R}$ - additional ship resistance in waves, $\mathrm{L}_{\mathrm{GW}}$ - hourly number of car deck flooding events in the place of broken side plating, respectively.

The values of the MIN operator as well as attribution function of the design criteria are given in Tab. 4 and Fig. 6.

Tab. 4. The values of the MIN operator as well as attribution function of the design criteria: MSI-motion sickness index, a -transverse acceleration at the car deck, $a_{v}$-vertical accelerations, $\varphi$ - significant amplitude of ship rolling, $R$ - additional ship resistance in waves, $L_{G W}$ - hourly number of car deck flooding events in the place of broken side plating

\begin{tabular}{|c|c|c|c|c|c|c|c|}
\hline Variants & $\mu(\mathbf{M S I})$ & $\boldsymbol{\mu}(\varphi)$ & $\boldsymbol{\mu}\left(\mathbf{a}_{\mathbf{v}}\right)$ & $\boldsymbol{\mu}\left(\mathbf{a}_{\mathbf{t}}\right)$ & $\boldsymbol{\mu}(\mathbf{R})$ & $\boldsymbol{\mu}\left(\mathbf{L}_{\mathbf{G W}}\right)$ & $\mathbf{M I N}$ \\
\hline $\begin{array}{c}\text { Variant } \\
\text { no. 1 }\end{array}$ & 0.000 & 0.000 & 0.000 & 0.000 & 0.000 & 1.000 & 0.000 \\
\hline $\begin{array}{c}\text { Variant } \\
\text { no. 2 }\end{array}$ & 0.043 & 0.132 & 0.000 & 0.406 & 0.939 & 0.000 & 0.000 \\
\hline $\begin{array}{c}\text { Variant } \\
\text { no. 3 }\end{array}$ & 0.218 & 1.000 & 0.135 & 1.000 & 1.000 & 1.000 & 0.135 \\
\hline $\begin{array}{c}\text { Variant } \\
\text { no. 4 }\end{array}$ & 1.000 & 1.000 & 1.000 & 1.000 & 0.000 & 0.000 & 0.000 \\
\hline $\begin{array}{c}\text { Variant } \\
\text { no. 5 }\end{array}$ & 1.000 & 0.000 & 1.000 & 0.000 & 0.112 & 0.000 & 0.000 \\
\hline $\begin{array}{c}\text { Variant } \\
\text { no. 6 }\end{array}$ & 1.000 & 0.000 & 1.000 & 0.000 & 0.213 & 0.000 & 0.000 \\
\hline $\begin{array}{c}\text { Variant } \\
\text { no. 7 }\end{array}$ & 0.726 & 0.000 & 0.622 & 0.000 & 0.377 & 0.000 & 0.000 \\
\hline $\begin{array}{c}\text { Variant } \\
\text { no. 8 }\end{array}$ & 1.000 & 0.313 & 1.000 & 0.625 & 1.000 & 0.473 & 0.313 \\
\hline
\end{tabular}

From Tab. 4 and Fig. 6 it results that variant no. 8 is of the best merits. 


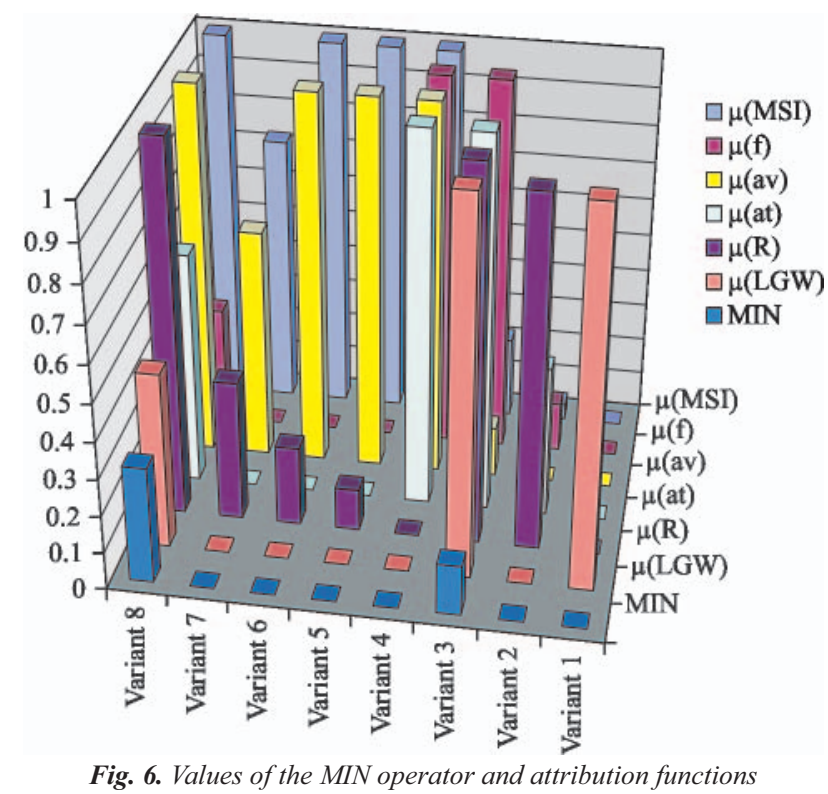

of the design variants

\section{THE $2^{\text {nd }}$ PHASE OF THE RESEARCH}

The $2^{\text {nd }}$ phase was aimed at determination of optimum design parameters of the ro-ro ferry under the following assumptions:

$-\mathrm{L} / \mathrm{B}=$ var

$-\mathrm{B} / \mathrm{d}=$ var

at the determined hull form complying with Variant no. 8, i.e.:

$$
\begin{aligned}
& -\mathrm{CB}=0.64 \\
& -\mathrm{CWL}=0.801
\end{aligned}
$$

as well as the earlier accepted design assumptions.

In the $1^{\text {st }}$ step a model set of design variants was elaborated and values of the design criteria were calculated. The same assumptions, calculation method and design criteria as in the $1^{\text {st }}$ phase, were used. The calculation results are presented in Tab. 5.

Next, approximations of values of the dependent variables were elaborated depending on the independent variables. The

Tab. 5. The model set of independent variables and dependent ones assumed in the design task of $C B=0,64, C W L=0,801$, where: $L-$ ship length, $B-$ ship breadth, $d$-ship draught, MSI-motion sickness index, $a_{t}$-transverse acceleration at the car deck, $a_{v}$-vertical accelerations, $\varphi$ - significant amplitude of

\begin{tabular}{|c|c|c|c|c|c|c|c|c|}
\hline \multirow{2}{*}{ Variants } & \multicolumn{2}{|c|}{$\begin{array}{c}\text { Independent } \\
\text { variables }\end{array}$} & \multicolumn{6}{|c|}{ Dependent variables } \\
\hline & $\begin{array}{c}\mathbf{L} / \mathbf{B} \\
{[-]}\end{array}$ & $\begin{array}{c}\text { B/d } \\
{[-]}\end{array}$ & MSI [\%] & $\begin{array}{c}\varphi \\
{\left[{ }^{0}\right]}\end{array}$ & $a_{v}\left[m / s^{2}\right]$ & $\begin{array}{c}\mathbf{a}_{t_{t}} \\
{\left[\mathbf{m} / \mathbf{s}^{2}\right]}\end{array}$ & $\underset{[\mathrm{kN}]}{\mathbf{R}}$ & $\mathbf{L}_{\mathrm{GW}}[\mathbf{1} / \mathbf{h}]$ \\
\hline Variant no.1 & 6.75 & 3.60 & 8.6 & 8.37 & 1.65 & 1.43 & 215.0 & 243.1 \\
\hline Variant no.2 & 4.11 & 3.53 & 24.6 & 12.06 & 1.88 & 2.06 & 224.9 & 264.2 \\
\hline Variant no. 3 & 4.99 & 3.53 & 35.3 & 10.02 & 1.99 & 1.72 & 207.6 & 280.4 \\
\hline Variant no.4 & 5.87 & 3.53 & 35.9 & 7.13 & 2.00 & 1.22 & 176.7 & 285.5 \\
\hline Variant no. 5 & 6.75 & 3.53 & 29.0 & 5.66 & 1.92 & 0.97 & 147.1 & 278.9 \\
\hline Variant no.6 & 3.23 & 3.22 & 8.2 & 8.20 & 1.64 & 1.41 & 206.0 & 236.9 \\
\hline Variant no.7 & 4.11 & 3.22 & 26.2 & 10.34 & 1.90 & 1.77 & 223.1 & 256.7 \\
\hline Variant no. 8 & 4.99 & 3.22 & 40.6 & 9.88 & 2.05 & 1.70 & 212.9 & 275.0 \\
\hline Variant no.9 & 5.87 & 3.22 & 43.7 & 7.11 & 2.08 & 1.22 & 183.0 & 285.2 \\
\hline Variant no. 10 & 6.75 & 3.22 & 38.4 & 5.52 & 2.02 & 0.95 & 150.7 & 282.4 \\
\hline Variant no. 11 & 3.23 & 3.84 & 8.7 & 9.13 & 1.65 & 1.56 & 220.8 & 247.4 \\
\hline Variant no. 12 & 4.11 & 3.84 & 100.0 & 12.87 & 13.70 & 2.20 & 225.9 & 269.2 \\
\hline Variant no. 13 & 4.99 & 3.84 & 30.0 & 9.84 & 1.94 & 1.69 & 203.1 & 282.9 \\
\hline Variant no. 14 & 5.87 & 3.84 & 28.8 & 7.11 & 1.92 & 1.22 & 171.9 & 284.0 \\
\hline Variant no. 15 & 6.75 & 3.84 & 21.2 & 5.82 & 1.83 & 1.00 & 150.7 & 278.7 \\
\hline Variant no. 16 & 3.23 & 4.15 & 8.5 & 10.59 & 1.64 & 1.80 & 226.8 & 250.3 \\
\hline Variant no. 17 & 4.11 & 4.15 & 20.4 & 13.68 & 1.82 & 2.34 & 226.2 & 271.8 \\
\hline Variant no. 18 & 4.99 & 4.15 & 25.3 & 9.57 & 1.88 & 1.63 & 200.1 & 282.6 \\
\hline Variant no. 19 & 5.87 & 4.15 & 22.8 & 7.15 & 1.85 & 1.22 & 170.6 & 281.1 \\
\hline Variant no. 20 & 6.75 & 4.15 & 15.8 & 6.23 & 1.75 & 1.07 & 149.3 & 279.2 \\
\hline Variant no. 21 & 3.23 & 4.46 & 8.0 & 12.16 & 1.63 & 2.07 & 230.6 & 252.7 \\
\hline Variant no. 22 & 4.11 & 4.46 & 17.9 & 14.14 & 1.79 & 2.41 & 225.4 & 274.6 \\
\hline Variant no. 23 & 4.99 & 4.46 & 21.3 & 9.47 & 1.83 & 1.61 & 199.8 & 282.4 \\
\hline Variant no. 24 & 5.87 & 4.46 & 17.8 & 7.24 & 1.78 & 1.23 & 171.4 & 277.9 \\
\hline Variant no. 25 & 6.75 & 4.46 & 11.3 & 6.63 & 1.68 & 1.13 & 153.9 & 278.2 \\
\hline
\end{tabular}
ship rolling, $R$-additional ship resistance in waves, $L_{G W}$ - hourly number of car deck flooding events in the place of broken side plating 
approximations were obtained by means of the artificial neural networks of MLP type (Multi Layer Perceptron) and presented with the use of Eqs. (3), (4), (5), (6), (7) and (8):

$$
\operatorname{MSI}=\frac{\left(\frac{1}{\left.1+\mathrm{e}^{-([\mathrm{L} / \mathrm{B}, \mathrm{B} / \mathrm{d}] \times \mathrm{S}+\mathrm{P}) \times \mathrm{A}-\mathrm{B})} \times \mathrm{C}-\alpha_{0}\right)-\alpha_{1}}\right.}{\alpha_{2}}
$$

where:

MSI - motion sickness index [\%]; L - ship length; B - ship breadth; d - ship draught; $\mathrm{A}$ - matrix of weighing factors:

$\left[\begin{array}{ccccccccccc}-0.311 & 0.921 & -0.694 & 5.134 & 2.302 & -1.432 & -3.048 & -3.136 & 0.695 & 0.098 & -0.090 \\ 0.957 & 2.041 & 0.917 & 2.913 & 1.206 & -0.194 & -0.191 & -1.058 & 0.459 & -0.254 & 0.123\end{array}\right]$

$\mathrm{S}$ - matrix of coefficients:

$$
\begin{aligned}
& {\left[\begin{array}{cc}
0.284 & 0 \\
0 & 0.806
\end{array}\right]} \\
& \mathrm{B} \text { - vector of threshold values: }
\end{aligned}
$$

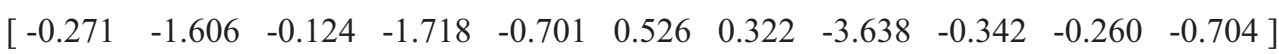

$$
\begin{aligned}
& \mathrm{C} \text { - column vector of weighing factors: }
\end{aligned}
$$

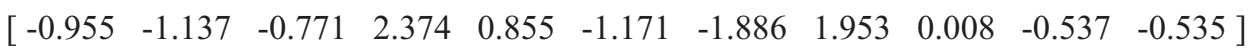

$$
\begin{aligned}
& \mathrm{P} \text { - vector of translation values: [ }-0.918-2.597 \text { ] } \\
& \alpha_{0}, \alpha_{1}, \alpha_{2} \text { - coefficients of the values: } \alpha_{0}=0.8, \alpha_{1}=-0.245, \alpha_{2}=0.031 \\
& \mathrm{R}=\frac{\left(\frac{1}{\left.1+\mathrm{e}^{-([\mathrm{L} / \mathrm{B}, \mathrm{B} / \mathrm{d}] \times \mathrm{S}+\mathrm{P}) \times \mathrm{A}-\mathrm{B})} \times \mathrm{C}-\alpha_{0}\right)-\alpha_{1}}\right.}{\alpha_{2}} \\
& \text { where: } \\
& \mathrm{R} \text { - additional ship resistance in waves, }[\mathrm{kN}] \\
& \text { A - matrix of values of weighing factors: } \\
& {\left[\begin{array}{ccccc}
-0.533 & -2.682 & 4.015 & 0.886 & -3.133 \\
0.065 & -0.252 & 1.285 & 1.316 & -0.798
\end{array}\right]} \\
& \text { B - vector of threshold values: }\left[\begin{array}{lllll}
-0.466 & 0.249 & 2.501 & 1.186 & -2.844
\end{array}\right] \\
& \mathrm{C}-\text { column vector of values of weighing factors: }\left[\begin{array}{lllll}
-0.350 & -2.402 & -1.706 & 1.705 & 1.517
\end{array}\right] \\
& \alpha_{0}, \alpha_{1}, \alpha_{2} \text { - coefficient of the values: } \alpha_{0}=-0.32, \alpha_{1}=-1.846, \alpha_{2}=0.013 \\
& \varphi=\frac{\left(\frac{1}{\left.1+\mathrm{e}^{-([\mathrm{L} / \mathrm{B}, \mathrm{B} / \mathrm{d}] \times \mathrm{S}+\mathrm{P}) \times \mathrm{A}-\mathrm{B})} \times \mathrm{C}-\alpha_{0}\right)-\alpha_{1}}\right.}{\alpha_{2}} \\
& \text { where: } \\
& \varphi \text { - significant roll amplitude }\left[^{\circ}\right] \\
& \text { A - matrix of values of weighing factors: } \\
& {\left[\begin{array}{ll}
3.869 & 5.902 \\
0.798 & 0.478
\end{array}\right]} \\
& \mathrm{B} \text { - vector of threshold values: [ } 0.530 \text { 2.873 ] } \\
& \mathrm{C} \text { - column vector of values of weighing factors: [ } 3.143-2.295 \text { ] } \\
& \alpha_{0}, \alpha_{1}, \alpha_{2} \text { - coefficients of the values: } \alpha_{0}=0.798, \alpha_{1}=-0.677, \alpha_{2}=0.123 \\
& a_{v}=\frac{\left(\frac{1}{1+e^{-([L / B, B / d] \times S+P) \times A-B)}} \times C-\alpha_{0}\right)-\alpha_{1}}{\alpha_{2}} \\
& \text { where: } \\
& a_{v} \text { - vertical accelerations }\left[\mathrm{m} / \mathrm{s}^{2}\right] \text {, } \\
& \text { A - matrix of values of weighing factors: }
\end{aligned}
$$

$\left[\begin{array}{cccccccccccccccc}1.76 & 0.38 & 2.19 & 0.58 & -0.92 & 0.89 & 0.19 & 0.50 & -0.21 & -0.14 & 0.70 & 0.88 & 0.11 & 0.47 & 3.88 & -1.57 \\ 0.12 & -0.40 & 0.12 & 1.02 & 0.25 & -0.84 & 0.98 & -0.29 & -1.12 & -0.14 & 0.95 & -0.30 & 0.48 & -0.11 & 1.18 & -0.32\end{array}\right]$




$$
\begin{aligned}
& \mathrm{B} \text { - vector of threshold values: } \\
& {\left[\begin{array}{llllllllllllllll}
-0.85 & -0.71 & -0.62 & 0.15 & 0.86 & -0.27 & -0.61 & -0.89 & 0.34 & 0.05 & 0.60 & 0.17 & 0.39 & -0.32 & 0.60 & -1.51
\end{array}\right]} \\
& \mathrm{C} \text { - column vector of values of weighing factors: }
\end{aligned}
$$

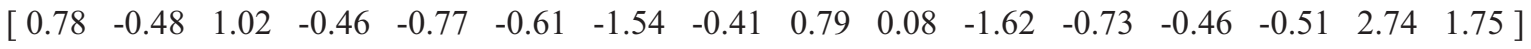

$$
\begin{aligned}
& \alpha_{0}, \alpha_{1}, \alpha_{2} \text { - coefficients of the values: } \alpha_{0}=0.157, \alpha_{1}=-3.727, \alpha_{2}=2.272 \\
& a_{t}=\frac{\left(\frac{1}{1+e^{-([L / B, B / d] \times S+P) \times A-B)}} \times C-\alpha_{0}\right)-\alpha_{1}}{\alpha_{2}} \\
& \text { where: } \\
& a_{t}-\text { transverse accelerations at the car deck, }\left[\mathrm{m} / \mathrm{s}^{2}\right] \\
& \text { A - matrix of values of weighing factors: } \\
& {\left[\begin{array}{ll}
3.862 & -6.941 \\
1.672 & -1.839
\end{array}\right]} \\
& \text { B - vector of threshold values: [ } 2.487-4.718 \text { ] } \\
& \left.\mathrm{C} \text { - column vector of values of weighing factors: [ } \begin{array}{ll}
2.662 & 2.562
\end{array}\right] \\
& \alpha_{0}, \alpha_{1}, \alpha_{2} \text { - coefficients of the values : } \alpha_{0}=2.449, \alpha_{1}=-0.674, \alpha_{2}=0.694 \\
& \mathrm{~L}_{\mathrm{GW}}=\frac{\left(\frac{1}{\left.1+\mathrm{e}^{-([\mathrm{L} / \mathrm{B}, \mathrm{B} / \mathrm{d}] \times \mathrm{S}+\mathrm{P}) \times \mathrm{A}-\mathrm{B})} \times \mathrm{C}-\alpha_{0}\right)-\alpha_{1}}\right.}{\alpha_{2}} \\
& \text { where: } \\
& \mathrm{a}_{\mathrm{v}}-\text { vertical accelerations, }\left[\mathrm{m} / \mathrm{s}^{2}\right] \\
& \text { A - matrix of values of weighing factors: } \\
& \left.\begin{array}{cccccccccccccc}
0.108 & -0.507 & -0.278 & -0.658 & 2.414 & -3.652 & -1.223 & 1.756 & 0.941 & -0.748 & -0.307 & 1.202 & 0.724 & 0.666 \\
0.363 & 0.154 & 0.064 & 0.538 & 0.079 & -0.409 & -0.370 & 0.887 & -0.521 & -0.856 & 0.533 & 0.346 & -0.174 & 0.424
\end{array}\right]
\end{aligned}
$$

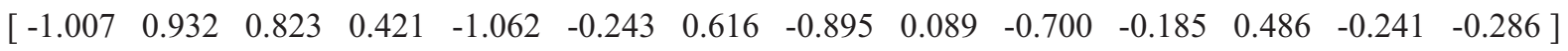

$$
\begin{aligned}
& \mathrm{C} \text { - column vector of values of weighing factors: }
\end{aligned}
$$

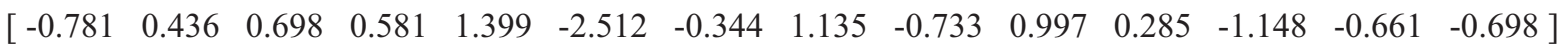

In Tab. 6. the above mentioned networks are described and their selected statistical parameters are given. From the data it results that the functions (3), (4), (5), (6), (7) and (8) have a simple structure and high accuracy.

Tab. 6. Structure and selected statistical parameters of the elaborated neural networks

\begin{tabular}{|c|c|c|c|c|}
\hline \multirow{2}{*}{ Variable } & \multirow{2}{*}{$\begin{array}{c}\text { Neural } \\
\text { network } \\
\text { structure }\end{array}$} & \multirow{2}{*}{$\begin{array}{c}\text { Correlation } \\
\text { coefficient } \mathbf{R}\end{array}$} & \multicolumn{2}{|c|}{$\begin{array}{c}\text { Mean square error } \\
\text { RMS }\end{array}$} \\
\cline { 4 - 5 } & of learning & $\begin{array}{c}\text { of } \\
\text { validation }\end{array}$ \\
\hline $\mathrm{MSI}$ & $2 \times 11 \times 1$ & 0.998 & 1.40 & 0.57 \\
\hline$\varphi$ & $2 \times 2 \times 1$ & 0.984 & 0.38 & 0.46 \\
\hline $\mathrm{R}$ & $2 \times 5 \times 1$ & 0.999 & 1.55 & 1.20 \\
\hline $\mathrm{a}_{\mathrm{t}}$ & $2 \times 2 \times 1$ & 0.997 & 0.09 & 0.04 \\
\hline $\mathrm{a}_{\mathrm{v}}$ & $2 \times 16 \times 1$ & 0.999 & 0.08 & 0.04 \\
\hline $\mathrm{L}_{\mathrm{GW}}$ & $2 \times 14 \times 1$ & 0.999 & 1.28 & 0.64 \\
\hline
\end{tabular}

In the further part of the research a hull form of the passenger car ferry was searched for with regard to the assumed criteria. To solve the problem the functions (2), (3), (4), (5), (6) and (7) were used.
In searching for a design solution which satisfies the assumed criteria the methods of one-criterial and multi-criterial optimization can be applied. However the main drawback of the methods is that they inform only where an optimum is located and they do not provide any information on a form of objective function, hence there is no certainty that the obtained solution is global optimum [4]. Number of possible combinations is relatively small as in the design task in question only two dependent variables of a rather small variability range appear. Therefore in order to determine an optimum solution the set of all possible design solutions was taken into account. For calculations the following increments of the design parameters were assumed:

$$
\Rightarrow \Delta \mathrm{L} / \mathrm{B}=0.01
$$$$
\Rightarrow \Delta \mathrm{B} / \mathrm{d}=0.01
$$

The calculation results were analyzed in the same way as in the $1^{\text {st }}$ phase of the research. To this end all design solutions were fuzzyfied by means of Eq. (1) and for their assessment the minimizing operator MIN acc. Eq. (2) was applied.

From the performed investigations it results that the best solution was obtaind for the following values of the design parameters :

O $\mathrm{L} / \mathrm{B}=6.72 \div 6.75$

○ $\mathrm{B} / \mathrm{d}=3.57 \div 3.80$ 
The value of the t-norm MIN for the above given solutions is presented in Fig. 7. Among them the design variant of $\mathrm{L} / \mathrm{B}=6.75$ and $\mathrm{B} / \mathrm{d}=3.60$ appears the best one. The optimum hull form of the ro-ro ferry is shown in Fig. 8.

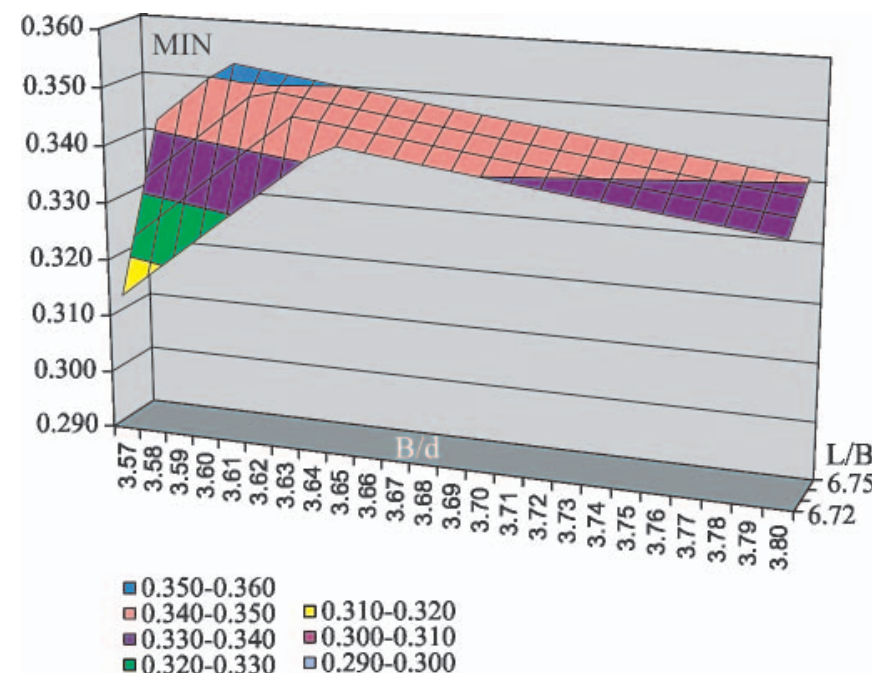

Fig. 7. Values of the t-norm MIN for the best design solutions, $C B=0.64, C W L=0.801, L / B=6.72 \div 6.75, B / d=3.57 \div 3.80$
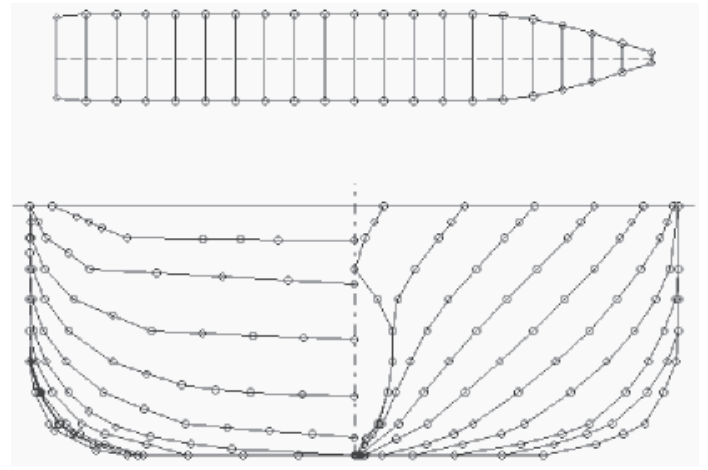

Fig. 8. The optimum hull form of the ro-ro ferry,

$V=13723 \mathrm{~m}^{3}, C B=0.64, C W L=0.801, L / B=6.75 \mathrm{iB} / \mathrm{d}=3.60$

To verify the result, values of the design criteria for the above given variant were determined (by using exact numerical methods) and then compared with the approximate ones. The results are shown in Tab. 7.

Tab. 7. Verification of the values of the design criteria for the optimum design variant, where: MSI - motion sickness index, a - transverse acceleration at the car deck, $a_{v}$-vertical accelerations, $\varphi$ - significant amplitude of ship rolling, $R$-additional ship resistance in waves,

$L_{G W}$ - hourly number of car deck flooding events in the place of broken side plating

\begin{tabular}{|c|c|c|c|c|c|c|}
\hline Method & $\begin{array}{c}\text { MSI } \\
{[\mathbf{\%}]}\end{array}$ & $\begin{array}{c}\boldsymbol{\varphi} \\
{\left[{ }^{\circ}\right]}\end{array}$ & $\begin{array}{c}\mathbf{a}_{\mathbf{v}} \\
{\left[\mathbf{m} / \mathbf{s}^{2}\right]}\end{array}$ & $\begin{array}{c}\mathbf{a}_{\mathbf{t}} \\
{\left[\mathbf{m} / \mathbf{s}^{2}\right]}\end{array}$ & $\begin{array}{c}\mathbf{R} \\
{[\mathbf{k N}]}\end{array}$ & $\begin{array}{c}\mathbf{L}_{\mathbf{G W}} \\
{[\mathbf{1} / \mathbf{h}]}\end{array}$ \\
\hline Appproximation & 29.3 & 5.99 & 1.90 & 0.98 & 147 & 278.5 \\
\hline Exact & 27.3 & 5.69 & 1.90 & 0.98 & 147 & 279.8 \\
\hline
\end{tabular}

\section{CONCLUSIONS}

In this paper a method which makes it possible to determine exact hull form of optimum ro-ro ferry with regard to many criteria, namely:

+ motion sickness index

+ rolling

+ transverse accelerations at the car deck
+ vertical accelerations

+ water flooding onto the car deck in the place of broken side plating

+ additional ship resistance in waves,

has been presented.

The elaborated method is partly based on exact numerical calculations and partly on approximations obtained with the use of artificial neural networks. To assess the design merits the method based on deterministic scenarios was applied, and decision as to the choice of the best solution was based on fuzzy logic elements. It made it possible to present design merits in the form of liguistic variables and to find a design variant being a compromise between partial targets.

The optimum hull form of the ferry, resulting from the approximation, was verified by means of exact numerical methods. As results from Tab. 7 the elaborated approximations appear very accurate, that can speak for that the design in question posseses appropriate (compromise) merits with regard to all partial criteria.

The presented approximations may be used to design analyses (e.g. acc. [1]) or as objective functions in other optimization methods of ship design parameters.

The presented approach, due to the fuzzy logic elements applied to the assessing of design variant merits, makes it possible to simplify a multi-criterial design problem to that one-criterial. In such case several partial criteria can be represented by a single criterion, e.g. the $t-$ norm minimizing operator, and solutions for which it reaches maximum can be searched for. Such approach may be used a.o. in optimization methods based on genetic algorithms.

\section{BIBLIOGRAPHY}

1. Cepowski T.: Approximation of the index for assessing ships sea-keeping performance on the basis of ship design parameters. Polish Maritime Research, No 3(53), Vol 14, 2007

2. Cepowski T.: Modeling the additional ship resistance in waves by means of ship hull form parameters (in Polish), (submitted to 2007' Transcomp Conference), 2007

3. Cepowski T.: Modeling design parameters of passenger car ferry with regard to selected sea-keeping qualities and additional ship resistance in waves, (to be published in Polish Maritime Research journal)

4. Chądzyński W.: Elements of contemporary design methods of floating objects (in Polish). Scientific Reports of Szczecin University of Technology (Prace Naukowe Politechniki Szczecińskiej), Department of Ocean Engineering and Marine Systems' Designing, Szczecin 2001

5. Frank W.: Oscillation of Cylinders in or below the Free Surface of Deep Fluids, Technical Report 2375, Naval Ship Research and Development Centre, Washington DC, U.S.A., 1967

6. Gerritsma, J. and Beukelman, W.: Analysis of the Resistance Increase in Waves of a Fast Cargo-ship. International Shipbuilding Progress, 18(217), 1972

7. Goldberg D.E.: Genetic Algorithms in Search, Optimization, and Machine Learning, published by Pearson Education, Inc, 1989

8. ITTC : Recommended Procedures and Guidelines, Model Tests on Damage Stability in Waves, 7.5-02, 07-04.2, 2005

9. Journée J.M.J. : Verification and Validation of Ship Motions Program SEAWAY. Report1213a, Delft University of Technology, The Netherlands, 2001

10.Kobyliński L.: Goal-based stability standards, Proceedings of the $9^{\text {th }}$ International Ship Stability Workshop, Germanischer Lloyd Operating 24/7, Hamburg 2007 
11. Lasdon, L.S., Waren, A.D.: Generalized reduced gradient software for linearly and nonlinearly constrained problems, in: Greenberg, H.J., (Ed.) Design and Implementation of Optimization Software. Sijthoff and Noordhoff, Holland, 1978

12. Ogawa Y.: An examination for the numerical simulation of parametric roll in head and bow seas, Proceedings of the $9^{\text {th }}$ International Ship Stability Workshop, Germanischer Lloyd Operating 24/7, Hamburg 2007

13.Pawłowski M.: Subdivision and damage stability of ships. Foundation for Promotion of Shipbuilding Industry and Maritime Economy (Fundacja Promocji Przemysłu Okrętowego i Gospodarki Morskiej), Gdańsk 2004

14.Riola J.M., M.Garcia de Arboleya: Habitability and personal space in seakeeping behaviour, Journal of Maritime Research, Vol III, No 1, 2006
15.Spanos D., Papanikolaou A.: On the Time to Capsize of a Damaged RoRo/Passenger Ship in Waves, Proceedings of the $9^{\text {th }}$ International Ship Stability Workshop, Germanischer Lloyd Operating 24/7, Hamburg 2007

16.Szozda Z.: A Concept of Ship Stability Criteria Based on Cargo Shift Caused by Rolling due to Gust, Scientific Reports (Zeszyty Naukowe) No. 2(74), Szczecin Maritime Academy, 2004

\section{CONTACT WITH THE AUTHOR}

Tomasz Cepowski, Ph. D.

Institute of Marine Navigation, Maritime University of Szczecin Wały Chrobrego 1/2

70-500 Szczecin, POLAND e-mail : cepowski@am.szczecin.pl

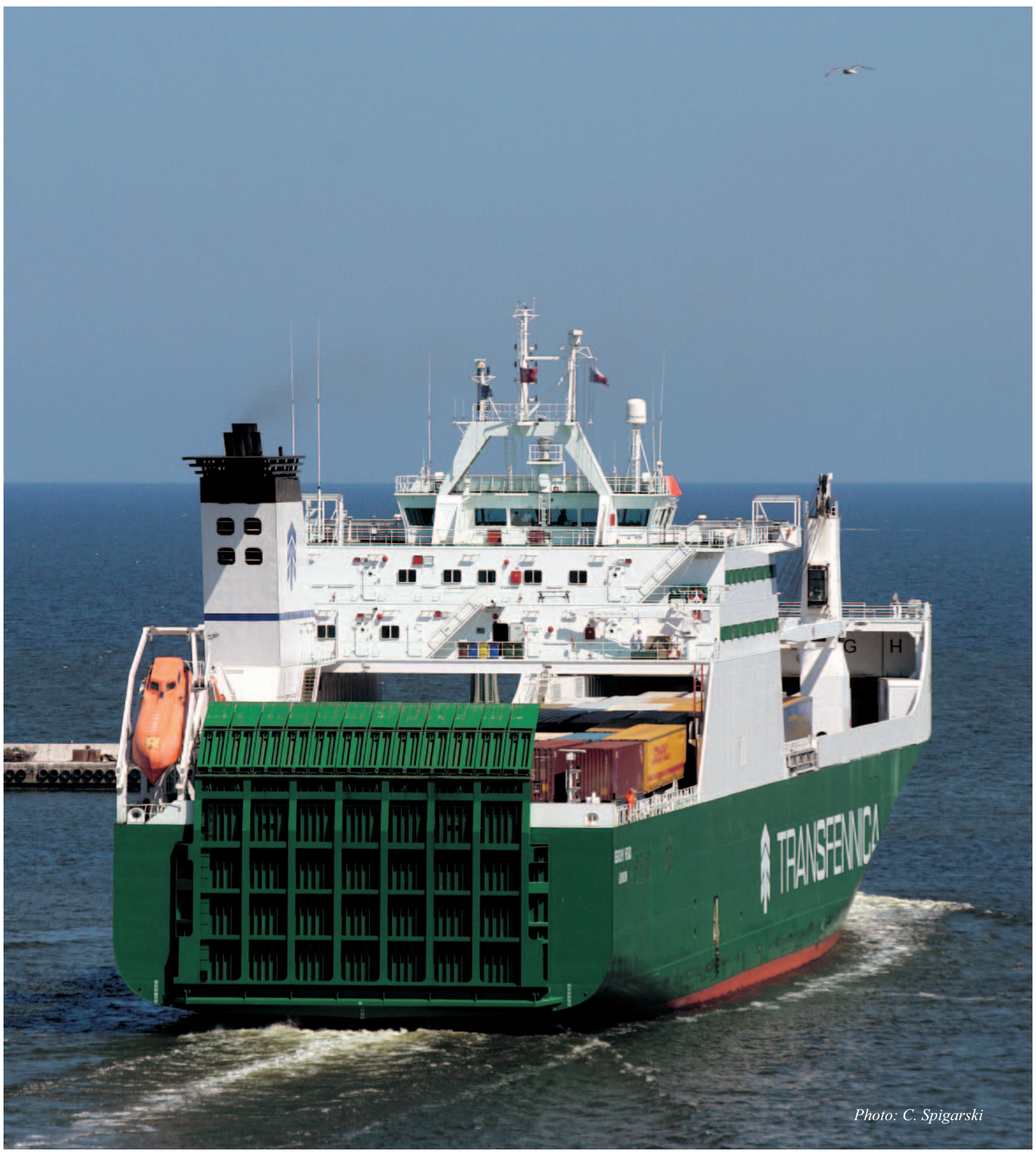

